\title{
Sterilisasi dan Pertumbuhan In Vitro Tunas Aksilar Pepaya Kultivar Callina dan Caliso
}

\author{
Sterilization and In Vitro Propagation of Axillary Shoots of Callina and Caliso Papaya Cultivars
}

\author{
Rahmi Fajri ${ }^{1}$, Darda Efendi ${ }^{2,3^{*}}$, dan Diny Dinarti ${ }^{2}$ \\ 'Program Studi Pemuliaan dan Bioteknologi Tanaman, Sekolah Pascasarjana, Institut Pertanian Bogor \\ ${ }^{2}$ Departemen Agronomi dan Hortikultura, Fakultas Pertanian, Institut Pertanian Bogor \\ (IPB University), Jl. Meranti, Kampus IPB Darmaga, Bogor 16680, Indonesia \\ ${ }^{3}$ Pusat Kajian Hortikultura Tropika, Institut Pertanian Bogor (IPB University), Kampus IPB Baranangsiang \\ Jl. Raya Pajajaran, Bogor 16144, Indonesia
}

Diterima 29 Desember 2020/Disetujui 26 Maret 2021

\begin{abstract}
Papaya medium and small types have been very popular in Indonesia since a decade ago. Most seed-derived papaya plants make a little profit because of heterogeneity and genetic variation due to cross-pollination, so that in vitro culture is needed. The research was conducted at the Tissue Culture Laboratory of the Center of Tropical Horticulture Studies, IPB University, from November 2018 to January 2020. The explants were axillary shoots of papaya cultivars Callina and Caliso which were 2 weeks old. The experiment was set up in a factorial randomized complete block design. This study consisted of two experiments: a) the first experiment aimed to determine the effect of sterilization methods, with the source of explants (greenhouse and field) and sterilization methods (M1, M2, M3, and M4) as factors, and b) the second experiment aimed to optimize the BAP and $G A_{3}$ concentration on shoots proliferation, using the concentrations of BAP 0.0, 0.5, 1.0, 1.5, and 2.0 $m g L^{-1}$ and $G A_{3} 0.0,0.3$, and $0.4 \mathrm{mg} \mathrm{L}^{-1}$. The results showed that the explants from the greenhouse on $M 4$ sterilization method produced the lowest contamination levels of $19.9 \%$ for Caliso and $29.9 \%$ for Callina. The best media to produce optimum shoot elongation were BAP $0.5 \mathrm{mg} \mathrm{L}^{-1}$ and $\mathrm{GA}_{3} 0.3 \mathrm{mg} \mathrm{L}^{-1}$ for Caliso, and BAP $0.5 \mathrm{mg} \mathrm{L}^{-1}$ and $\mathrm{GA}_{3} 0.4 \mathrm{mg} \mathrm{L}^{-1}$ for Callina with an average height of 1.6 and $1.8 \mathrm{~cm}$, so that that shoots can be transferred to the rooting stage.
\end{abstract}

Keywords: Benzyl Amino Purine, Carica papaya, contamination, gibberellic acid, sterilization

\section{ABSTRAK}

Pepaya tipe sedang dan kecil sudah digemari di Indonesia sejak satu dekade lalu. Sebagian besar tanaman pepaya yang diperbanyak dari biji menghasilkan profit yang rendah karena heterogenitas dan variasi genetik yang diakibatkan oleh penyerbukan silang, sehingga diperlukan kegiatan secara kultur in vitro. Penelitian dilakukan di Laboratorium Kultur Jaringan Pusat Kajian Hortikultura Tropika (PKHT) IPB, Bogor, dari November 2018 hingga Januari 2020. Eksplan merupakan tunas aksilar pepaya kultivar Callina dan Caliso umur 2 minggu. Penelitian dirancang secara faktorial dalam lingkungan Rancangan Acak Kelompok (RAK). Penelitian ini dibagi menjadi dua percobaan: a) Percobaan pertama bertujuan untuk mengetahui pengaruh metode sterilisasi dengan faktor sumber eksplan (rumah kaca dan lapangan) dan metode sterilisasi (M1, M2, M3, dan M4), dan b) Percobaan kedua bertujuan untuk optimalisasi konsentrasi BAP dan GA $A_{3}$ pada pertumbuhan tunas dengan konsentrasi BAP 0.0, 0.5, 1.0, 1.5, dan $2.0 \mathrm{mg} \mathrm{L} \mathrm{L}^{-1}$, dan konsentrasi GA 0.0 , 0.3, dan $0.4 \mathrm{mg} \mathrm{L}^{-1}$. Hasil penelitian menunjukkan bahwa eksplan dari rumah kaca pada sterilisasi metode M4 menghasilkan tingkat kontaminasi terendah yaitu 19.9\% untuk Caliso dan 29.9\% untuk Callina. Media terbaik untuk menghasilkan tinggi tunas optimum adalah BAP $0.5 \mathrm{mg}$ $L^{-1}$ dan $\mathrm{GA}_{3} 0.3 \mathrm{mg} \mathrm{L} \mathrm{L}^{-1}$ untuk Caliso dan BAP $0.5 \mathrm{mg} \mathrm{L}^{-1}$ dan $\mathrm{GA}_{3} 0.4 \mathrm{mg} \mathrm{L}^{-1}$ untuk Callina dengan tinggi rata-rata 1.6 dan 1.8 $\mathrm{cm}$, sehingga tunas dapat dipindahkan ke tahap pengakaran.

Kata kunci: Asam giberelat, Benzyl amino purine, Carica papaya, kontaminasi, sterilisasi

\section{PENDAHULUAN}

Pepaya (Carica papaya L.) tipe sedang dan kecil sudah sangat digemari oleh masyarakat Indonesia sejak satu

\footnotetext{
* Penulis untuk korespondensi. e-mail: dardaefendi@gmail.com
}

dekade silam. Keunggulan pepaya dengan tipe sedang dan kecil diantaranya memiliki ukuran yang hanya setengah dari pepaya biasa sehingga dapat dikonsumsi sekali habis dan didukung dengan rasanya yang manis (Sobir, 2009). Permintaan buah pepaya tipe ini semakin meningkat seiring dengan meningkatnya pendapatan dan kesadaran masyarakat terhadap manfaat pepaya bagi kesehatan tubuh. 
Pusat Kajian Hortikultura Tropika (PKHT) telah melakukan pengembangan varietas tanaman pepaya unggul sejak tahun 2000. Terdapat beberapa kultivar unggul yang telah dihasilkan diantaranya Caliso dan Callina. Pepaya Caliso yang merupakan salah satu kultivar unggulan lokal asal Kalimantan yang masuk dalam kategori ukuran buah kecil (19.5-21.4 cm) dan Callina merupakan varietas unggulan nasional yang termasuk dalam kategori buah ukuran sedang $(23-24 \mathrm{~cm})$.

Perbanyakan tanaman papaya pada umumnya dilakukan dengan biji, namun tipe seks pepaya yang ditumbuhkan melalui benih baru dapat ditentukan setelah tanaman berumur 6 bulan atau munculnya bunga pertama (Roy et al., 2012). Selain itu persilangan antartanaman menghasilkan segregasi dengan proporsi seks yang berbedabeda, sehingga mengakibatkan terjadinya variasi terhadap produktivitas, kualitas, dan bentuk buah pepaya (Chan et al., 2002).

Pengembangan protokol perbanyakan pepaya kultivar Caliso dan Callina secara in vitro perlu dilakukan untuk mendapatkan propagula yang banyak, seragam dan true to type. Keberhasilan perbanyakan secara in vitro dapat menunjang penyediaan bibit pepaya yang banyak, cepat dan berkualitas untuk para petani pepaya. Keuntungan pemanfaatan proliferasi tunas aksilar yaitu tunas lebih stabil secara genetik dan sangat sedikit atau tidak ada variasi genetik (Ngezahayo dan Liu, 2014). Induksi proliferasi tunas aksilar telah berhasil dilakukan pada pepaya, tetapi tingkat keberhasilannya masih sangat rendah (Al-Shara et al. 2018). Permasalahan ini disebabkan oleh kontaminasi mikroba bakteri endogen, terutama bila eksplan berasal dari tanaman dewasa yang ditanam di lapangan dan tingkat proliferasi yang rendah (Caple et al., 2016).

Studi sterilisasi tunas aksilar pepaya telah dilaporkan oleh Wu et al. (2012) dan Hervani et al. (2018). Kedua peneliti menggunakan antibiotik rifampicin $300 \mathrm{mg} \mathrm{L}^{-1}$ dengan cara merendam eksplan sebelum ditanam untuk mengurangi kontaminasi pada kultur tunas pepaya yang berasal dari lapangan. Terdapat eksplan yang bebas kontaminasi meskipun hasilnya belum memuaskan. Oleh sebab itu, perlu dilakukan modifikasi teknik sterilisasi pada eksplan yang berasal dari lapangan dan rumah kaca.

Tahapan multiplikasi tunas dapat dilakukan dengan menambahkan zat pengatur tumbuh dari golongan sitokinin secara tunggal atau dikombinasikan dengan golongan auksin). Dari dua jenis sitokinin (BAP dan kinetin), maka BAP terbaik dalam merespon regenerasi tunas dibandingkan dengan kinetin jika dikombinasikan dengan NAA(Nguyen et al., 2018). Setargie et al. (2015) menyatakan bahwa jumlah tunas terbanyak diperoleh dari media MS yang diperkaya dengan $1 \mathrm{mg} \mathrm{L}^{-1}$ BAP dan $0.5 \mathrm{mg} \mathrm{L}^{-1}$ NAA. Berbeda dengan Bindu (2015) yang jumlah tunas terbanyak diperoleh pada kombinasi $0.5 \mathrm{mg} \mathrm{L}^{-1} \mathrm{BAP}$ dan $0.1 \mathrm{mg} \mathrm{L}^{-1} \mathrm{NAA}$ pada kultivar CO-5. Perbedaan tersebut dimungkinkan karena perbedaan genotipe dan eksplan yang digunakan. Wu et al. (2012) melaporkan bahwa tunas yang dihasilkan dari tahap perbanyakan belum dapat dimasukan pada tahap pengakaran karena memiliki tunas yang pendek dan daun kerdil. Selain itu Ramesh et al., 2018 juga menyatakan bahwa tanpa penambahan $\mathrm{GA}_{3}$ tunas pepaya gagal memanjang, sehingga penambahan $\mathrm{GA}_{3}$ sangat diperlukan untuk memacu pertumbuhan dan pemanjangan tunas. Kombinasi ZPT terbaik untuk menginduksi pemanjangan tunas adalah BAP $0.25 \mathrm{mg} \mathrm{L}^{-1}$ dan $\mathrm{GA}_{3} 0.3 \mathrm{mg} \mathrm{L}^{-1}$ (Wu et al., 2012, Caple et al., 2016). Tujuan dari penelitian ini adalah untuk mengetahui pengaruh metode sterilisasi dan pertumbuhan tunas aksilar pepaya Caliso dan Callina pada kombinasi BAP (Benzyl Amino Purine) dan $\mathrm{GA}_{3}$ (Gibberellic Acid).

\section{BAHAN DAN METODE}

Penelitian ini dilaksanakan pada bulan November 2018 sampai Januari 2020 di Laboratorium Pusat Kajian Hortikultura Tropika (PKHT) IPB. Bahan tanam adalah eksplan dari tunas aksilar pepaya kultivar Caliso dan Callina dengan ukuran $0.5-1 \mathrm{~cm}$. Persiapan penanaman dilakukan dengan menyemai dua benih pepaya per lubang dalam polybag dan dua bulan kemudian bibit dipindahkan ke lapangan dan rumah kaca. Setelah 4-5 bulan muncul bunga pertama tanaman pepaya. Tanaman pepaya yang dipilih berjenis kelamin hermaprodit. Selanjutnya dilakukan pemotongan tajuk pepaya hingga menyisakan batang dengan tinggi 80-100 cm dari tanah. Dua minggu setelah pemotongan tajuk, tunas aksilar yang tumbuh dari batang pohon pepaya dan dapat dipanen untuk dijadikan eksplan atau bahan tanam.

\section{Sterilisasi Tunas}

Percobaan dilaksanakan secara terpisah pada dua kultivar pepaya yaitu Caliso dan Callina. Rancangan percobaan disusun berdasarkan Rancangan Acak Kelompok (RAK) faktorial, dengan faktor pertama yaitu sumber asal eksplan (lapangan dan rumah kaca) dan faktor kedua adalah metode sterilisasi (M1, M2, M3, dan M4) maka terdapat 8 kombinasi perlakuan yang setiap perlakuan diulang $10 \mathrm{kali}$, sehingga terdapat 80 satuan percobaan. Satu unit percobaan merupakan satu botol kultur yang berisi 4 eksplan.

Perlakuan sterilisasi pada tunas aksilar pepaya terdiri dari empat metode yaitu: (1) M1 (Metode Dasar) merupakan metode modifikasi dari penelitian Hervani et al. (2018), dimana tunas aksilar yang telah diambil kemudian direndam dalam larutan surfaktan $2 \mathrm{~mL}$ dalam $500 \mathrm{~mL}$ air selama 30 menit lalu diairi dengan air mengalir selama 60 menit. Kemudian eksplan diambil dan direndam kembali dalam larutan yang sudah diberi benlate dan agrept masing-masing $2 \mathrm{mg} \mathrm{L}^{-1}$ selama 60 menit pada gelas ukur dan diletakkan pada inkubator bergoyang (shaker). Proses sterilisasi selanjutnya dilakukan di dalam laminar yaitu pembilasan sebanyak 3 kali dengan aquadest steril kemudian diberi perlakuan sterilisasi dengan $\mathrm{NaOCl}$ bertingkat yaitu 30\% selama 5 menit, $15 \%$ selama 15 menit dan 5\% selama 5 menit. Setelah perlakuan dengan $\mathrm{NaOCl}$ kemudian dibilas dengan aquadest steril sebanyak 5 kali dan kemudian 
direndam dengan menggunakan antibiotik rifampicin $2 \mathrm{~g} \mathrm{~L}^{-1}$ selama 15 menit. (2) $\mathrm{M}_{2}$ yaitu metode dasar yang sebelumnya didahului dengan penyemprotan tunas aksilar pada pohon pepaya dengan alkohol $70 \%$ sebanyak 1 liter untuk 30 tanaman sebelum pengambilan eksplan. (3) $M_{3}$ yaitu metode dasar yang sebelumnya didahului dengan penyemprotan tunas aksilar pada pohon pepaya dengan benlate dan agrept masing-masing $1 \mathrm{gr} \mathrm{L}^{-1}$ untuk 30 tanaman pada sore hari sebelum pengambilan eksplan pada pagi hari berikutnya. (4) M4 yaitu metode dasar yang dilengkapi dengan perlakuan penyemprotan benlate dan agrept masing-masing $1 \mathrm{~g} \mathrm{~L}^{-1}$ untuk 30 tanaman pepaya pada sore hari sebelum pengambilan tunas aksilar dan dilakukan perendaman eksplan yang telah dipanen pada aquadest steril dengan suhu rendah $\left(4-8{ }^{\circ} \mathrm{C}\right)$ selama 60 menit.

Tunas aksilar yang telah disterilisasi kemudian ditanam pada media inisiasi tunas pepaya yaitu MS yang diperkaya dengan $1.0 \mathrm{mg} \mathrm{L}^{-1} \mathrm{BAP}$ dan $0.5 \mathrm{mg} \mathrm{L}^{-1} \mathrm{NAA}$ (Wardani et al., 2019). Setelah 4 minggu di media inisiasi lalu disubkultur pada media dengan komposisi yang sama selama 4 minggu, kemudian tunas yang beregenerasi dari eksplan dipindahkan ke media perlakuan BAP dan $\mathrm{GA}_{3}$ pada percobaan ke-2. Pengamatan dilakukan setiap dua minggu sekali selama 8 minggu dengan variabel yang diamati adalah persentase kontaminasi tunas dan jumlah eksplan hidup.

\section{Pertumbuhan Tunas Aksilar Pepaya dengan Penambahan Konsentrasi BAP dan $G A_{3}$}

Percobaan dilaksanakan secara terpisah pada dua kultivar pepaya yaitu Caliso dan Callina. Rancangan percobaan yang digunakan adalah rancangan acak kelompok faktorial dengan waktu penanaman sebagai kelompok. Faktor pertama yaitu konsentrasi BAP yang terdiri dari 5 taraf yaitu $0.0 ; 0.5 ; 1.0 ; 1.5$; dan $2.0 \mathrm{mg} \mathrm{L}^{-1}$. Faktor kedua yaitu konsetrasi $\mathrm{GA}_{3}$ terdiri dari 3 taraf yaitu $0.0 ; 0.3$ dan $0.4 \mathrm{mg} \mathrm{L}^{-1}$. Terdapat 15 kombinasi perlakuan dengan 4 kali ulangan, sehingga total menjadi 60 botol unit percobaan. Satu unit percobaan merupakan satu botol kultur yang berisi 2 eksplan.

Tunas yang digunakan sebagai eksplan adalah tunas bebas kontaminasi dari percobaan pertama yang berumur 8 minggu. Tunas yang siap dipindahkan minimal memiliki tinggi tunas $0.5 \mathrm{~cm}$ dan 3 helai daun. Selanjutnya eksplan diinkubasi pada ruang kultur dengan waktu terang 16 jam dan gelap 8 jam pada suhu $22 \pm 2{ }^{\circ} \mathrm{C}$. Eksplan disubkultur setiap dua minggu, dimana tunas hasil subkultur pertama menjadi eksplan untuk subkultur selanjutnya hingga subkultur ke empat. Pengamatan dilakukan setiap dua minggu sekali (sebelum disubkultur) selama 10 minggu dengan variabel yang diamati yaitu jumlah tunas per eksplan, tinggi tunas per eksplan dan jumlah daun per eksplan.

Data yang diperoleh dalam pengamatan kemudian diolah dengan Microsoft Excel 2016 dan dianalisis keragamannya (ANOVA) dengan program Statistical Analysis Software (SAS) versi 9.1. Hasil ANOVA yang berbeda nyata kemudian diuji lanjut dengan Duncan Multiple Range Test (DMRT).

\section{HASIL DAN PEMBAHASAN}

\section{Tingkat Kontaminasi Kultur}

Hasil pengamatan pada perlakuan metode sterilisasi menunjukkan bahwa tingkat kontaminasi tertinggi pada tunas yang berasal dari lapangan. Persentase kontaminasi tertinggi mencapai $100 \%$ untuk kedua kultivar pepaya asal lapangan dan $80 \%$ untuk tunas asal rumah kaca pada sterilisasi metode dasar $\left(\mathrm{M}_{1}\right)$. Eksplan asal rumah kaca memiliki lingkungan tumbuh tanaman lebih terkontrol baik dari penyinaran, kelembaban, pengaruh hujan dan dari serangan hama penyakit. Kontaminasi terendah diperoleh pada metode sterilisasi M4 untuk seluruh kultivar asal rumah kaca dengan kisaran 20-30\% (Gambar 1).

Perlakuan sterilisasi dengan metode dasar tidak efektif dilakukan karena perlakuan dengan metode dasar tidak optimal mengurangi kontaminasi. Meskipun bahan sterilan yang digunakan mengandung sabun, $\mathrm{NaOCl}$ dan rifampicin. Prosedur prasterilisasi dan sterilisasi dapat mengurangi kontaminasi, Benazir et al. (2013) juga mengemukakan bahwa kontaminasi dapat diminimalkan dengan melakukan dua tahap sterilisasi.

Penyemprotan alkohol 70\% yang kemudian dilanjutkan dengan metode dasar pada tunas aksilar pepaya $\left(\mathrm{M}_{2}\right)$ kurang efektif karena eksplan banyak mengalami kerusakan sehingga warna berubah menjadi putih dan kehitaman sampai mengalami kematian. Perlakuan penyemprotan benlate dan agrept masing-masing $1 \mathrm{~g} \mathrm{~L}^{-1}$ sehari sebelum pengambilan eksplan $\left(\mathrm{M}_{3}\right)$ dapat menurunkan tingkat kontaminasi hingga mencapai $20-45 \%$ pada eksplan asal rumah kaca, sedangkan pada eksplan asal lapangan tingkat kontaminasinya masih tinggi dengan persentase $70-76 \%$. Metode M4 (metode dasar yang dilengkapi dengan perlakuan penyemprotan benlate dan agrept pada sore hari sebelum pengambilan tunas aksilar dan dilakukan perendaman eksplan pada aquadest steril bersuhu $4-8{ }^{\circ} \mathrm{C}$ ) cukup efektif menurunkan kontaminasi dengan persentase kontaminasi akhir mencapai $19.9 \%$ pada kultivar Caliso dan $29.9 \%$ pada kultivar Callina. Hal ini diduga karena perendaman dengan air steril bersuhu $4-8{ }^{\circ} \mathrm{C}$ dapat mengurangi aliran getah

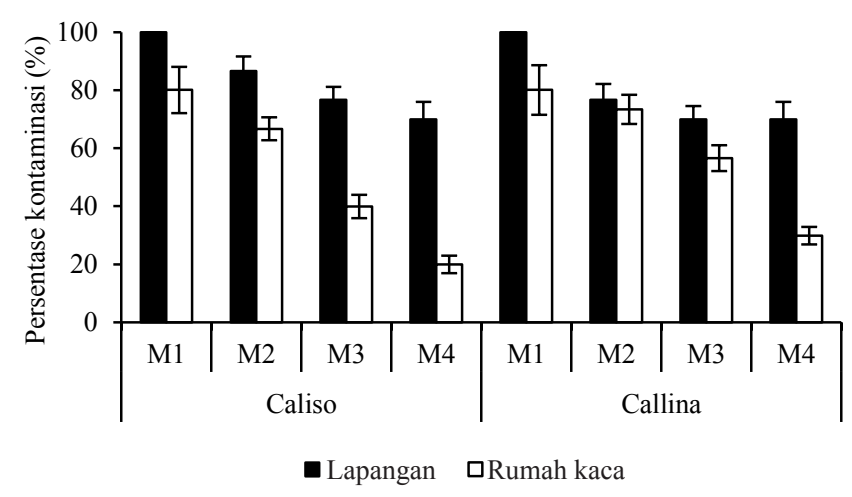

Gambar 1. Persentase kontaminasi pada kultur in vitro tunas aksilar pepaya kultivar Caliso dan Callina asal lapangan dan rumah kaca pada empat perlakuan metode sterilisasi. $\operatorname{Bar} \pm$ S.E. 
tunas pepaya yang diperkirakan menjadi salah satu sebab terjadinya kontaminasi.

Bakteri endogen telah dilaporkan menjadi salah satu permasalahan utama pada kultur jaringan tunas pepaya yang sulit dihindari karena bakteri telah berasosiasi dengan tanaman sehingga sulit dideteksi pada awal inisiasi (Thomas dan Kumari, 2010, Wu et al., 2012). Perendaman eksplan dengan larutan rifampicin $2 \mathrm{~g} \mathrm{~L}^{-1}$ selama 15 menit pada perlakuan sterilisasi menjadi hal penting untuk mengurangi kontaminasi akibat bakteri. Gejala kontaminasi oleh bakteri endogen tunas pepaya muncul setelah dilakukan proses subkultur atau setelah proses pemisahan clum tunas. Eksplan yang berasal dari lapangan lebih banyak mengalami kontaminasi tetapi perbedaan kultivar tidak mempengaruhi persentase kontaminasi.

Eksplan yang telah dimultiplikasi membutuhkan penanganan lebih lanjut untuk bisa disiapkan kelapangan, salah satunya dengan menginduksi perpanjangan tunas (elongasi). Hal ini bertujuan agar tunas kokoh sehingga saat memasuki tahapan aklimatisasi planlet akan mampu berfotosintesis. Tunas-tunas pepaya yang terbentuk pada fase induksi dan multiplikasi memiliki ukuran yang pendek, sehingga perlu dilakukan penginduksian pemanjangan tunas.

Selama eksplan pada media inisiasi dan multiplikasi $1.0 \mathrm{mg} \mathrm{L}{ }^{-1}$ BAP dan $0.5 \mathrm{mg} \mathrm{L}^{-1} \mathrm{NAA}$, tunas pepaya mengalami proliferasi dengan waktu rata-rata 3-4 minggu dengan laju multiplikasi rata-rata 3 tunas per eksplan dalam waktu 8 minggu. Tunas yang tumbuh merupakan hasil inisiasi tunas pepaya yang kemudian dilakukan pemisahan dari clum tunas. Dari pemisahan tunas tersebut diperoleh 48 tunas Caliso asal lapangan, 112 tunas Caliso asal rumah kaca, 48 tunas Callina asal lapangan dan 100 tunas Callina asal rumah kaca. Total tunas hasil dari lapangan dan rumah kaca digabung berdasarkan kultivar untuk selanjutnya dijadikan eksplan untuk Percobaan 2.
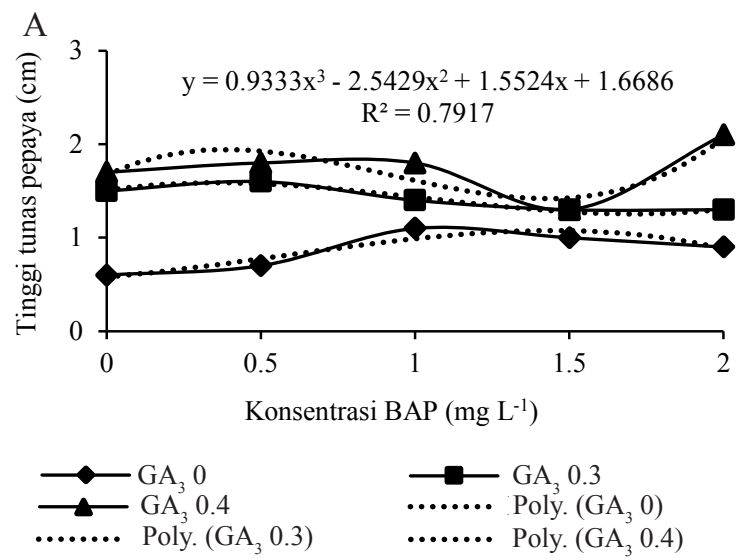

\section{Pertumbuhan Kultivar Caliso}

Respon tinggi tunas pada kultur tunas pepaya Caliso perlakuan BAP $0.0,0.5,1,1.5$, atau $2 \mathrm{mg} \mathrm{L}^{-1}$ berbeda pada perlakuan $\mathrm{GA}_{3}$ dengan konsentrasi $0,0.3$, dan 0.4 mg L ${ }^{-1}$. Gambar 2A menunjukkan bahwa perlakuan BAP dikombinasikan dengan $\mathrm{GA}_{3} 0.4 \mathrm{mg} \mathrm{L}^{-1}$ membentuk kurva kubik dengan persamaan $\mathrm{y}=0.933 \mathrm{x}^{3}-2.542 \mathrm{x}^{2}+1.552 \mathrm{x}+$ 1.668 dan $\mathrm{R}^{2}=0.791$ dengan tinggi tunas maksimum sebesar $2.3 \mathrm{~cm}$. Secara morfologi tunas pepaya Caliso perlakuan BAP $2.0 \mathrm{mg} \mathrm{L}^{-1}$ dan $\mathrm{GA}_{3} 0.4 \mathrm{mg} \mathrm{L}^{-1}$ memiliki warna hijau pucat dengan daun yang menebal dan berwarna putih. Hal ini menunjukkan gejala keracunan BAP karena tunas terpapar BAP pada konsentrasi tinggi waktu yang lama. Setargie et al. (2015) telah mengkonfirmasi bahwa penggunaan BA $2 \mathrm{mg} \mathrm{L}^{-1}$ menyebabkan perubahan bentuk pada morfologi tunas dan daun in vitro pepaya varietas Maradol. Berbeda dengan tunas yang diperoleh pada perlakuan BAP $0.5 \mathrm{mg}$ $\mathrm{L}^{-1}$ dan $\mathrm{GA}_{3} 0.3 \mathrm{mg} \mathrm{L}^{-1}$ yang memiliki rata-rata tinggi tunas berkisar $1.6 \mathrm{~cm}$ dengan bentuk yang kompak serta daun berwarna hijau, sehingga tunas dapat dipindahkan pada media pengakaran. Hal ini sesuai dengan informasi oleh $\mathrm{Wu}$ et al. (2012) yaitu kriteria tinggi tanaman yang siap untuk dipindahkan ke tahap pengakaran minimal $1.5 \mathrm{~cm}$ dan Setargie et al. (2015) dimana tunas yang siap untuk dipindahkan pada media pengakaran memiliki tinggi 1.0 $1.8 \mathrm{~cm}$ dan berkualitas baik.

Jumlah tunas tidak dipengaruhi oleh faktor tunggal ataupun interaksi antara BAP dan $\mathrm{GA}_{3}$. Hal ini mungkin disebabkan oleh ketidakseragaman respon dari setiap eksplan dan periode subkultur yang terlalu singkat yaitu 2 MST. Perlakuan subkultur dengan periode 2 MST diharapkan agar pertumbuhan tunas meningkat akan tetapi sistem regenerasi tanaman pepaya lambat (slow growing) yang ditandai dengan munculnya pertambahan tunas pertama setelah 4 MST. Tunas dapat mengalami stagnasi pertumbuhan

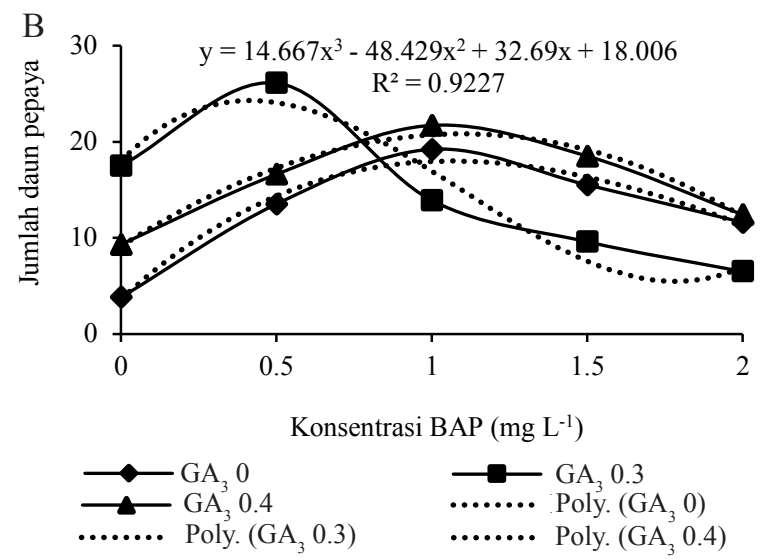

Gambar 2. Respon (A) tinggi tunas dan (B) jumlah daun pada eksplan pepaya kultivar Caliso pada perlakuan BAP 0.0, 0.5, 1, 1.5, dan 2 mg L ${ }^{-1}$ pada tingkat $\mathrm{GA}_{3} 0,0.3$, dan $0.4 \mathrm{mg} \mathrm{L}^{-1}$ pada umur $10 \mathrm{MST}$ 
karena tindakan subkultur yang berlebihan. Samanmalie et al. (2017) menyatakan bahwa subkultur tunas pepaya baik dilakukan dengan frekuensi 4 minggu.

Jumlah daun umur 10 minggu pada perlakuan BAP $0.5 \mathrm{mg} \mathrm{L}^{-1}$ dan $\mathrm{GA}_{3} 0.3 \mathrm{mg} \mathrm{L}^{-1}$ (Gambar 2B) efektif untuk mendorong pertumbuhan jumlah daun total dibandingkan perlakuan lainnya. Meskipun $\mathrm{GA}_{3}$ secara tunggal tidak berpengaruh karena fungsinya tidak mendukung pembentukan daun akan tetapi memacu pemanjangan daun. Daun pepaya yang baik memiliki karakteristik memiliki ukuran sesuai dengan tunasnya dan tidak menggulung atau membuka sempurna.

\section{Pertumbuhan Kultivar Callina}

Interaksi BAP $0.5 \mathrm{mg} \mathrm{L} \mathrm{L}^{-1}$ dan $\mathrm{GA}_{3} 0.4 \mathrm{mg} \mathrm{\textrm {L } ^ { - 1 }}$ menghasilkan tinggi tunas optimum $1.8 \mathrm{~cm}$ dengan membentuk pola $\mathrm{y}=1.533 \mathrm{x}^{3}-4.714 \mathrm{x}^{2}+3.645 \mathrm{x}+1.052$ dan $\mathrm{R}^{2}=0.787$ (Gambar 3B). Menurut Wu et al. (2012) tinggi tunas yang baik untuk dimasukkan tahap pengakaran minimal $1.5 \mathrm{~cm}$. Berdasarkan kriteria tersebut maka kombinasi perlakuan BAP $0.5 \mathrm{mg} \mathrm{L}^{-1}$ dan $\mathrm{GA}_{3} 0.4 \mathrm{mg} \mathrm{L}^{-1}$ dapat menghasilkan tunas yang memenuhi kriteria untuk dimasukkan ke tahap pengakaran.

Komposisi media MS dengan BAP $0.5 \mathrm{mg} \mathrm{L}^{-1}$ dan $\mathrm{GA}_{3} \quad 0.3 \mathrm{mg} \mathrm{L}^{-1}$ merupakan media terbaik dalam pembentukan tunas dengan rata-rata 2.6 tunas per eksplan pada 10 MST (Tabel 1). Jumlah tunas yang dihasilkan dari penelitian ini lebih kecil dibandingkan dengan hasil penelitian Wu et al. (2016) dan yang mencapai 4 tunas per eksplan pada kombinasi media $0.25 \mathrm{mg} \mathrm{L}^{-1}$ dan $\mathrm{GA}_{3} 0.3 \mathrm{mg}$ $\mathrm{L}^{-1}$. Perbedaan respon jumlah tunas dapat disebabkan karena perbedaan genotipe yang berkaitan dengan kandungan endogen yang ada dalam sistem tanaman. Perbedaan respon tunas dapat disebabkan karena perbedaan genotipe dan eksplan yang digunakan. Konsentrasi BAP yang digunakan peneliti antara $0.25-2.00 \mathrm{mg} \mathrm{L}^{-1}$ dan konsentrasi $\mathrm{GA}_{3}$ yaitu $0.1-1.0 \mathrm{mg} \mathrm{L}^{-1}$. Faktor tunggal BAP berpengaruh nyata terhadap jumlah tunas diduga karena BAP telah berada pada konsentrasi optimal sehingga memacu pembelahan sel dan mempengaruhi lintasan diferensiasi sel tanaman (Davies 2004). Penambahan $\mathrm{GA}_{3}$ secara tunggal tidak memberikan pengaruh nyata pada penambahan jumlah tunas pepaya Callina. Hal ini didukung oleh pernyataan Wu et al. (2012) bahwa $\mathrm{GA}_{3}$ dapat menginduksi pemanjangan tunas tetapi mengurangi pembentukan jumlah tunas.

Pemberian beberapa konsentrasi $\mathrm{GA}_{3}$ yang berbeda pada selang $0.3 \mathrm{mg} \mathrm{L}^{-1}$ yang dikombinasikan dengan BAP $\left(0,0.5,1.0,1.5\right.$, dan $\left.2 \mathrm{mg} \mathrm{L}^{-1}\right)$ mendorong pertambahan jumlah daun pepaya dengan persamaan $\mathrm{y}=20.33 \mathrm{x}^{3}-65.4 \mathrm{x}^{2}$ $+49.71 x+3.69$ dan $\mathrm{R}^{2}=0.980$ (Gambar 3C). Pertambahan jumlah daun maksimum pada tunas pepaya kultivar Callina diperoleh pada $\mathrm{GA}_{3} 0.3 \mathrm{mg} \mathrm{L}^{-1}$ yang dikombinasikan dengan BAP $0.5 \mathrm{mg} \mathrm{L}^{-1}$ sebesar 14.7 daun per tunas. Penggunaan $\mathrm{GA}_{3}$ secara tunggal akan menghasilkan tunas dengan berdaun kecil. Ramesh et al. (2018) juga menyebutkan juga bahwa $\mathrm{GA}_{3}$ dengan konsentrasi yang tinggi (lebih dari $1 \mathrm{mg} \mathrm{L}^{-1}$ ) juga dapat menyebabkan bentuk daun

Tabel 1. Jumlah tunas pepaya kultivar Callina perlakuan BAP dan GA 3 pada minggu ke-2 sampai minggu ke-10

\begin{tabular}{|c|c|c|c|c|c|c|}
\hline \multirow{2}{*}{\multicolumn{2}{|c|}{$\begin{array}{l}\text { BAP : GA } \\
\left(\mathrm{mg} \mathrm{L}^{-1}\right)\end{array}$}} & \multicolumn{5}{|c|}{ MST (minggu setelah tanam) } \\
\hline & & \multirow{2}{*}{$\begin{array}{l}2 \\
1\end{array}$} & \multirow{2}{*}{$\frac{4}{1.2 \mathrm{bcde}}$} & \multirow{2}{*}{$\frac{6}{1.3 \mathrm{bcd}}$} & \multirow{2}{*}{$\frac{8}{1.3 \mathrm{def}}$} & \multirow{2}{*}{$\frac{10}{1.3 \mathrm{cdef}}$} \\
\hline 0.0 & 0.0 & & & & & \\
\hline 0.0 & 0.3 & 1 & $1.1 \mathrm{cde}$ & $1.3 \mathrm{bcd}$ & $1.5 \mathrm{bcdef}$ & $1.5 \mathrm{bcdef}$ \\
\hline 0.0 & 0.4 & 1 & $1.1 \mathrm{cde}$ & $1.3 \mathrm{bcd}$ & $1.4 \mathrm{bcdef}$ & $1.4 \mathrm{bcdef}$ \\
\hline 0.5 & 0.0 & 1 & $1.0 \mathrm{de}$ & $1.3 \mathrm{bcd}$ & $1.5 \mathrm{bcdef}$ & $1.5 \mathrm{bcdef}$ \\
\hline 0.5 & 0.3 & 1 & $1.7 \mathrm{a}$ & $2.0 \mathrm{a}$ & $2.5 \mathrm{a}$ & $2.6 \mathrm{a}$ \\
\hline 0.5 & 0.4 & 1 & $1.4 \mathrm{abcd}$ & $1.6 \mathrm{abc}$ & $1.7 \mathrm{bcd}$ & $1.7 \mathrm{bcd}$ \\
\hline 1.0 & 0.0 & 1 & $1.1 \mathrm{cde}$ & $1.2 \mathrm{~cd}$ & $1.2 \mathrm{ef}$ & $1.2 \mathrm{ef}$ \\
\hline 1.0 & 0.3 & 1 & $1.3 \mathrm{bcde}$ & $1.3 \mathrm{bcd}$ & $1.5 \mathrm{bcdef}$ & $1.5 \mathrm{bcdef}$ \\
\hline 1.0 & 0.4 & 1 & $1.3 \mathrm{bcde}$ & $1.4 \mathrm{bcd}$ & $1.5 \mathrm{bcdef}$ & $1.5 \mathrm{bcdef}$ \\
\hline 1.5 & 0.0 & 1 & $1.6 \mathrm{ab}$ & $1.7 \mathrm{ab}$ & $1.9 \mathrm{bc}$ & $1.9 \mathrm{bc}$ \\
\hline 1.5 & 0.3 & 1 & $1.0 \mathrm{de}$ & $1.0 \mathrm{~d}$ & $1.0 \mathrm{f}$ & $1.0 \mathrm{f}$ \\
\hline 1.5 & 0.4 & 1 & $1.5 \mathrm{abc}$ & $1.6 \mathrm{ab}$ & $2.0 \mathrm{ab}$ & $2.0 \mathrm{~b}$ \\
\hline 2.0 & 0.0 & 1 & $1.5 \mathrm{abc}$ & $1.6 \mathrm{ab}$ & $1.6 \mathrm{bcde}$ & 1.6bcde \\
\hline 2.0 & 0.3 & 1 & $1.3 \mathrm{bcde}$ & $1.3 \mathrm{bcd}$ & $1.4 \mathrm{cdef}$ & $1.4 \mathrm{bcdef}$ \\
\hline 2.0 & 0.4 & 1 & $1.2 \mathrm{bcde}$ & $1.2 \mathrm{~cd}$ & $1.2 \mathrm{ef}$ & $1.2 \mathrm{def}$ \\
\hline \multicolumn{3}{|c|}{$\mathrm{KK}(\%)$} & 16 & 19 & 23 & 23 \\
\hline
\end{tabular}

Keterangan: Angka yang diikuti huruf yang sama pada kolom yang sama menunjukkan tidak berbeda nyata berdasarkan DMRT pada $\alpha=$ $5 \%$ 
tunas abnormal sehingga tunas tidak dapat dipindahkan ke tahap pengakaran. Konsentrasi terbaik dalam menghasilkan pertumbuhan tunas optimum diperoleh pada kombinasi
BAP $0.5 \mathrm{mg} \mathrm{L}^{-1}$ dan $\mathrm{GA}_{3} 0.3 \mathrm{mg} \mathrm{L}^{-1}$ untuk Caliso dan BAP $0.5 \mathrm{mg} \mathrm{L}^{-1}$ dan $\mathrm{GA}_{3} 0.3 \mathrm{mg} \mathrm{L}^{-1}$ untuk Callina.
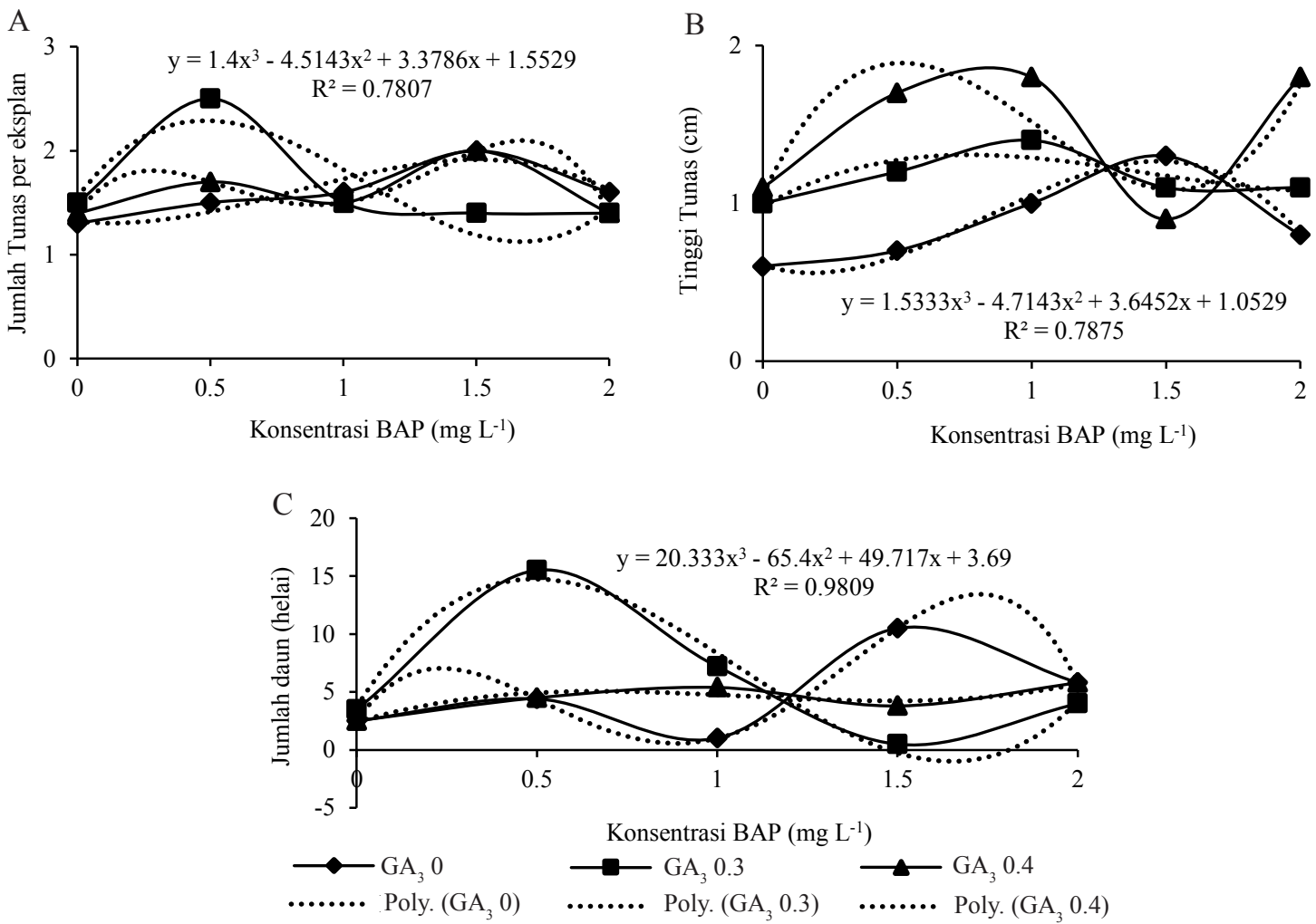

Gambar 3. Respon (A) jumlah tunas, (B) tinggi tunas dan (C) jumlah daun pada eksplan pepaya kultivar Callina pada perlakuan BAP 0, $0.5,1,1.5$, dan $2 \mathrm{mg} \mathrm{L}^{-1}$ pada tingkat $\mathrm{GA}_{3} 0,0.3$, dan $0.4 \mathrm{mg} \mathrm{L}^{-1}$ pada umur $10 \mathrm{MST}$

\section{KESIMPULAN}

Eksplan tunas aksilar dengan persentase kontaminasi terendah berasal dari pepaya yang ditanam di rumah kaca dengan proses sterilisasi metode M4 yaitu penyemprotan benlate dan agrept masing-masing $1 \mathrm{~g} \mathrm{~L}^{-1}$ sehari sebelum pengambilan eksplan, kemudian dilakukan perendaman eksplan pada aquadest steril bersuhu rendah $\left(4-8{ }^{\circ} \mathrm{C}\right)$ dan dilanjutkan dengan perlakuan sterilisasi metode dasar dengan menghasilkan tingkat kontaminasi yang rendah yaitu $19.9 \%$ untuk Caliso dan $29.9 \%$ untuk Callina. Media terbaik untuk menghasilkan tinggi tunas optimum adalah $\mathrm{GA}_{3} 0.3 \mathrm{mg} \mathrm{L}^{-1}$ dan BAP $0.5 \mathrm{mg} \mathrm{L}^{-1}$ untuk pepaya kultivar Caliso serta $\mathrm{GA}_{3} 0.4 \mathrm{mg} \mathrm{L}^{-1}$ dan BAP $0.5 \mathrm{mg} \mathrm{L}^{-1}$ untuk Callina. Tinggi tunas optimum yang diperoleh Caliso dan Callina pada media tersebut adalah 1.6 dan $1.8 \mathrm{~cm}$, sehingga tunas siap untuk dipindahkan ke tahap pengakaran.

\section{DAFTAR PUSTAKA}

Al-Shara, B., R.M. Taha, K. Rashid. 2018. Biotechnological methods and limitations of micropropagation papaya (Carica papaya L.) production [Review]. J. Anim. Plant Sci. 28:1208-1226.
Benazir, J.F., R. Suganthi, P. Chandrika, B. Mathithumila. 2013. In vitro regeneration and transformation studies on Pelargonium grave-olens (geranium) -an important medicinal and aromatic plant. J. Medicine Plant Res. 38:2815-2822.

Bindu, B. 2015. Micro propagation of papaya variety CO-5. IJRAF. 2:46-49.

Caple, A.D., K.T. Cheah. 2016. Micropropagation of hermaprodit Carica papaya L. 'Rainbow' seedlings via axillary bud pathway. Biotechnology BIO-12. CTAHR. University of Hawaii. Hawaii, US.

Chan, L.K., C.K.H. Teo. 2002. Micropropagation of Eksotika, a Malaysian papaya cultivar, and the field performance of the tissue culture derived clones. Acta Hort. 575:99-105.

Davies, P.J. 2004. Plant Hormones: Biosynthesis, Signal Transduction, Actions!. Kluwer Academic Pr. Dordrecth, Netherlands, NL. 
Hervani, D., D. Efendi, M.R. Suhartanto, B.S. Purwoko. 2018. The preservation of somatic embryos of papaya derived from papaya lateral shoots after being stored in cryopreservation to maintain plant genetic information in the future. Biodiversitas 19:774-779.

Ngezahayo, F., B. Liu. 2014. Axillary bud proliferation approach for plant biodiversity conservation and restoration. Biodiver. Conserv. 3:1-9.

Nguyen, V.H., Yen, C.H. Hsieh. 2018. Effect of nutritional and growth hormonal factors on in vitro regeneration of papaya (Carica papaya L. cv. Red Lady). J. Nath. Sci. Foundation Sri Langka 46: 559-568.

Ramesh, A.N., D.B. Santhosh, D. Suresh, K. Radha, K. Rashmi, K. Hajira. 2018. In vitro regeneration of papaya (Carica papaya L.) variety Surya. Int. J. Pure App. Biosci. 6:456-461.

Roy, P.K., S.K. Roy, M.L. Hakim. 2012. Propagation of papaya (Carica papaya L.) cv. Shahi through in vitro culture. Bangladesh J. Bot. 41:191-195.

Samanmalie, L.G.I., B.M.V.S. Basnayke, A. Rohini, K.G.G. Indika. 2017. Developing a tissue culture protocol for production of planting materials of papaya (Carica papaya L.) hybrid. Ann. Sri Lanka Dept. Agric. 19:45-52.

Setargie, A., F. Mekbib, E. Abraha. 2015. In vitro propagation of papaya (Carica papaya L.). World J. Agric. Sci. 11:84-88.

Sobir. 2009. Sukses Bertanam Pepaya Unggul Kualitas Supermarket. Agromedia Pustaka, Jakarta, ID.

Thomas, P., S. Kumari. 2010. Inconspicuous endophytic bacteria mimicking latex exudates in shoot tip cultures of papaya. Sci. Hort. 124:469-474.

Wardani, F.F., D. Efendi, D. Dinarti, J.K. Winoto. 2019. Perbanyakan pepaya (Carica papaya L.) 'Sukma' in vitro dari eksplan tunas pucuk sebagai respon terhadap BA dan NAA. J. Agron. Indonesia 47:203209.

Wu, K., S. Zeng, Z. Chen, J. Duan. 2012. In vitro mass propagation of hermaproditic Carica papaya cv Meizhonghong. Pak. J. Bot. 44:1669-1676. 